\title{
Research of directional project teaching in Higher Vocational Education
}

\author{
Wei Guanghui ${ }^{1, a}$ \\ 1.ChongQing College of Electronic Engineering, computer college,ChongQing,401331, china \\ a.Email: qdbiq@163.com
}

Abstract: This paper discusses the type of project oriented teaching method to solve the many problems arising from the traditional project-based teaching, the teaching process will be set to the development needs of enterprises and industries oriented to enterprise project for teaching material, through the " two combination ", namely: the teaching process with the combination of business and industry, the process of teaching and teachers and the environment combine to achieve project oriented teaching style. Using Directional project teaching, can the full integration of social education resources, closely linked social development of various industries and enterprises of demand, improve the overall quality of talent in higher vocational colleges to meet corporate demand for vocational talents.

Keywords: Directional project teaching ; industry; enterprise; teacher; surroundings

\section{Introduction}

Vocational College mission is to train social needs of production, service, construction, management of skilled personnel, providing companies with a qualified professional competence of professional quality talent. Practitioner professional competence refers directly affect the efficiency of the professional activity, the ability to make professional activity can be carried out smoothly, including practitioners of knowledge, skills and attitudes, and many other aspects [1].

Since the country opened colleges, experts and scholars engaged in vocational education has been kept on how to keep fit with the social development needs of the teaching mode. According to this article with more vocational colleges nationwide survey, combined with the direction of development of the industry and the employment needs of companies, proposed a " Directional Project Teaching " approach.

\section{The main problem with traditional teaching methods}

Higher Vocational Colleges of our country in the process of teaching to explore and summarize all kinds of teaching mode, which is the most extensive project teaching, the teaching mode in Higher Vocational Colleges of our country's education has been advocated for many years, but according to the social enterprise in higher vocational colleges teaching effect of feedback information, the result is not optimistic. The reason is mainly adopt the method of project while teaching in the teaching process, but mostly on the knowledge structure of teaching materials in the textbooks as a framework to virtual, hypothetical or outdated project as a case. Using this traditional project teaching, it did not pay attention to the needs of the introduction of contemporary enterprises, did not keep up with the pace of the development of the corresponding industry.

Specifically, this phenomenon is mainly caused by the following two deep-seated factors.

\subsection{The standard problem of the introduction of talents in Higher Vocational Colleges}

the academic requirements of teachers as a necessary condition, relatively relaxed teachers' industry experience and work experience, which leads to the introduction of curriculum for the teachers and the actual work needs, and how the development of the industry dynamic combination of lack of correct and comprehensive understanding, in the project teaching process is a multi reference already eliminated, outdated and hypothetical case, resulting in failure of the teaching effect; at the same time, if the establishment of professional personnel training plan of the teachers lack related working experience in relevant industries, and the relevant experts in the planning process is not involved in this industry. It will cause the teaching orientation of Higher Vocational College deviation, the students in the knowledge structure, work ability, work attitude etc. Will not meet the needs of enterprises and the needs of the development of the industry. 


\subsection{Environmental problems in Teaching}

The teaching environment of higher vocational colleges is a major factor to restrict the quality of project teaching in higher vocational colleges. Although the country is recognized on the project teaching in higher vocational colleges, and in recent years, the project teaching environment improvement and increased capital investment, but from the actual demand is still a big gap, owing to the limitation of national economic development level, can not be unlimited funding in Higher Vocational colleges. To this end, most of the higher vocational colleges use the social forces to make up for the lack of project teaching practice, which is the form of school enterprise cooperation. However, the cooperation also has many problems, such as cooperation without legal protection, lack of awareness of school and enterprise cooperation, development and the needs of the enterprise school teaching plan does not conform to the enterprise cooperation does not actually significant leading enterprises to participate in the enthusiasm is not enough, which will essentially affect the the quality of project teaching.

How to solve the deficiency of traditional project teaching? This paper discusses a kind of oriented project teaching method which is based on the traditional project teaching theory.

\section{Implementation of directional Project Teaching}

Here we advocate " Directional Project Teaching ", " Directional " is to determine the direction of teaching, this direction is "to guide the direction of development of the industry"; "Project teaching" is "to the enterprise project for teaching material". It is in the higher vocational college courses teaching, teaching goal orientation to the enterprise and the industry, the introduction of enterprise recent case, in these cases as the teaching material, so as to ensure the teaching practicality and timeliness; selection of teaching cases, must be based on the current to the development needs of industry as the guiding direction, if selected in the process of teaching the case does not have the typical significance, development can not be on behalf of the needs of the industry and the industry, this is the case of a failure case.

In order to realize the " Directional Project Teaching ", the core idea is to design the teaching process as the "two combination", namely, the teaching process and the enterprise and industry, the combination of teaching process and teaching staff and environment.

\subsection{Teaching process and the combination of enterprise and Industry}

The concept of enterprise and industry. The enterprise is engaged in the production, circulation, services and other economic activities, production or service to meet the needs of society, a non-profit implementation of autonomous, independent accounting, established in accordance with the law of economic organization. Industry refers to the economic activities of the same kind of products or services provided by the same kind of labor service. The development of the industry to follow the law from the low natural resources utilization and predatory exploitation of lower labor output, gradually to the scale of economy, science and technology intensive, financial intensive, talent intensive, knowledge economy, output from natural resources, gradually turned to the output of industrial products, intellectual property, high-tech talent etc..

From the above concept can be seen, the enterprise is for the purpose of profit, and the cultivation of talents in higher vocational colleges, enterprises should realize this requirement, but if the higher vocational colleges in training students, not in-depth understanding of specific demand for talent in the enterprise, will make higher vocational graduation students lack the ability to work in the corresponding occupation, companies involved in the specific work, will make the enterprise production efficiency is greatly reduced, will directly affect the profitability of enterprises, reduce the market competitiveness of enterprises. This has led to a contradiction between the enterprise and higher vocational graduates of supply and demand contradiction: the enterprise needs the talent to recruit, the students graduate employment is difficult. Makes a lot of enterprises in the new higher vocational graduates in the post, but also spend a lot of time and money to carry out the training of higher vocational graduates, or to provide some new low skill labor jobs. From the law of development of the industry is visible, any industry development constantly, in order to meet the needs for the development of the higher 
vocational education must follow the dynamic development of the industry, teaching orientation should be consistent with the development of the industry.

Higher vocational education should be combined with the industry and enterprises, to strengthen the construction of professional connotation, in order to adapt to the social demand for talents. The direction of education in higher vocational colleges, should be based on the industry association based on the object, make industry association to participate in the professional training objectives and teaching direction; the teaching process of higher vocational colleges, need to be enterprise partners, allow enterprises to fully participate in the higher education institutions to. There are a variety of college and enterprise cooperation mode, such as cooperation, teaching factory, alternation, these different ways of cooperation can be selected according to the difference between the higher vocational colleges and universities set up specific professional nature, so as to realize the students to learn in school with the enterprise practice, let the school and enterprise equipment and technology complementary advantages, resource sharing, in order to improve the pertinence and effectiveness of higher vocational education, improve the quality of skilled personnel.

\subsection{The combination of teaching process and teaching staff and environment}

In the front, the problem of traditional project teaching is discussed, which is mainly the problem of teachers and the environment. So here we explore how to solve these problems by directional teaching methods.

A considerable part of the teachers in higher vocational colleges, due to the lack of relevant industry experience, to truly realize the oriented project teaching, it is necessary to effectively improve the teaching staff. Can be used to send out and the introduction of a combination of ways to solve the problem of teachers. The "send" includes two meanings: one is to establish the cooperation between school and enterprises, school teachers according to their professional expertise in theory, to the enterprise employees from the perspective of professional training, to improve the overall quality of the staff, so as to create value for the enterprise production; two is the higher vocational college according to the different professional, to develop appropriate teacher training mechanism, make teachers enterprises work environment, enterprises in the production process, operation process of the master project specific enterprise case, in order to achieve the true sense of the project teaching method in daily teaching. "Introduction" refers to according to the actual needs of the enterprise, outstanding managers, engineers, professional and technical personnel of enterprises into the school to teach students, so that students can receive from the actual case, the "Introduction" of teachers can be fixed, long period, can also according to the temporary to determine the needs of college. In the implementation of the introduction of enterprise teachers, the appointment of the conditions should be changed to the main form of education to practice based.

The teaching environment provides the necessary places to achieve directional education in higher vocational colleges, to perfect the teaching plan, and excellent teachers, the teaching process must be in a will provide the necessary teaching environment to fully implement. The improvement of the teaching environment on one hand is the need to state funding the establishment of specialized training base, but more important is the requirement of higher vocational colleges has a kind of "active": higher vocational colleges set up according to their own professional, the establishment of specialized departments, responsible for related enterprises and social communication, make full use of existing social resources. In the selection and way of enterprise, a school enterprise cooperation, teaching factory, alternation etc., but the school enterprise cooperation and combination of two ways, according to the practice has obvious deficiency, school enterprise cooperation will adversely affect the daily production of enterprises, and the alternation of teaching order will disrupt school the factory is most consistent with the way of teaching the teaching mode of higher vocational colleges, the occupation colleges in Singapore has been a very good application, the teaching factory can ensure the orientation of project teaching can have a good environment, can make the teaching and keep up with the pace of development of social needs.

\section{Summary}

The use of oriented project teaching, can the full integration of social education resources, demand development is closely related to all sectors of society and the development of enterprises, according to the change 
of science and technology, develop training plan, and in the project oriented teaching, synchronous development and modification of materials, to provide students with the latest and most timely the application of knowledge, but also according to the needs of industries and enterprises, timely opening of the new curriculum, so as to improve the comprehensive quality of talents cultivation in higher vocational colleges, higher vocational talents to meet the needs of enterprises.

\section{References}

1 Chen HaiBing,Fan Jian. NPY Teaching Factory and Its Inspiration[J].Communication of Vocational Education 2004.6(3):58-59.

2 ZHANG Jinliang, JIN Xianghong, WANG Jiarong. "Directionality" in Course Reform and Practice [J].Journal of Ningbo University of Technology. 2012 24(1):71-73.

3 Huang Yani. The Comparative Research on the Pattern of the Cooperation of School and Enterprise of Higher Vocational Education[J].Vocational and Technical education 2004, 25( 28):15-18

4 Wang Xing,Dong Mengmeng. Based on Cooperation of School - enterprise Employment Oriented [J].Chinese Vocational and Technical Education.2014,(28):89-91.

5 Zhao Ming. Carry out the project of teaching, improve the quality of teaching and learning[J]. Science \& Technology Information.2008,(19).270.

6 Bill Tucker. The Flipped Classroom: Online Instruction at Home Frees Class for Learning [EB/OL]. [2013-05-18].http://educationnext.org/files/ednext_20121_BTucker.pdf.

7 Mendi Benigni. Reverse Classroom-changing Your Course Delivery in Exchange for Mastery [EB/OL]. [2012-05-01].http://blogs.cofc.edu/tlt/2010/10/20/reverse -classroom -\% E2\% 80\% 93 -changingyour-course-delivery-in-exchange-for-mastery/.

8 Bergmann J. \& Sams A. March 2012 . The Flipped Class What it is and What it is Not. http //www.thedailyriff.com/articles/the-flipped-class-conversation-689.php

9 Yang Zhaohua. Talking about the teaching of information technology projects Teaching Method [J]. China Educational Technology \& Equipment, 2012,(23):95-97. 